\title{
Zeaxanthin-Rich Extract from Superfood Lycium barbarum Selectively Modulates the Cellular Adhesion and MAPK Signaling in Melanoma versus Normal Skin Cells In Vitro
}

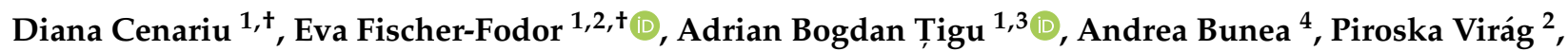 \\ Maria Perde-Schrepler ${ }^{2}{ }^{(D}$, Vlad-Alexandru Toma ${ }^{3,5,6}$, Andrei Mocan $7,8, *\left(\mathbb{D}\right.$, Ioana Berindan-Neagoe ${ }^{2,9}{ }^{(1)}$, \\ Adela Pintea ${ }^{4}$ (D), Gianina Crișan ${ }^{7}$, Mihai Cenariu ${ }^{10, *}$ and Alma Maniu ${ }^{11}$ (I)
}

1 Medfuture Research Center for Advanced Medicine, University of Medicine and Pharmacy, "Iuliu Hatieganu", RO-400012 Cluj-Napoca, Romania; diana.cenariu@umfcluj.ro (D.C.); fischer.eva@iocn.ro (E.F.-F.); adrianbogdantigu@gmail.com (A.B.T.)

2 Institute of Oncology “I. Chiricuta”, 34-36 Republicii Street, RO-400015 Cluj-Napoca, Romania; vpiroska@yahoo.com (P.V.); pmariaida@yahoo.com (M.P.-S.); ioananeagoe29@gmail.com (I.B.-N.)

3 Faculty of Biology and Geology, Babeș-Bolyai University, RO-400015 Cluj-Napoca, Romania; vlad.al.toma@gmail.com

4 Department of Chemistry and Biochemistry, University of Agricultural Sciences and Veterinary Medicine, RO-400372 Cluj-Napoca, Romania; andrea.bunea@usamvcluj.ro (A.B.); apintea@usamvcluj.ro (A.P.)

5 Institute of Biological Research Cluj-Napoca, Branch of NIRDBS Bucharest, 400015 Cluj-Napoca, Romania

6 National Institute for Research and Development of Isotopic and Molecular Technologies, RO-400293 Cluj-Napoca, Romania

check for updates

Citation: Cenariu, D.; Fischer-Fodor,

E.; Tigu, A.B.; Bunea, A.; Virág, P.;

Perde-Schrepler, M.; Toma, V.-A.;

Mocan, A.; Berindan-Neagoe, I.;

Pintea, A.; et al. Zeaxanthin-Rich

Extract from Superfood Lycium

barbarum Selectively Modulates the

Cellular Adhesion and MAPK

Signaling in Melanoma versus

Normal Skin Cells In Vitro. Molecules

2021, 26, 333. https://doi.org/

$10.3390 /$ molecules 26020333

Academic Editor: Raffaele Capasso

Received: 25 November 2020

Accepted: 2 January 2021

Published: 11 January 2021

Publisher's Note: MDPI stays neutral with regard to jurisdictional clai$\mathrm{ms}$ in published maps and institutional affiliations.

Copyright: $\odot 2021$ by the authors. Licensee MDPI, Basel, Switzerland. This article is an open access article distributed under the terms and conditions of the Creative Commons Attribution (CC BY) license (https:// creativecommons.org/licenses/by/ $4.0 /)$.
7 Department of Pharmaceutical Botany, University of Medicine and Pharmacy "Iuliu Hatieganu", RO-400337 Cluj-Napoca, Romania; gcrisan@umfcluj.ro

8 Laboratory of Chromatography-ICHAT, University of Agricultural Sciences and Veterinary Medicine, RO-400372 Cluj-Napoca, Romania

9 Research Center for Functional Genomics, Biomedicine and Translational Medicine, "Iuliu Hatieganu", University of Medicine and Pharmacy, RO-400012 Cluj-Napoca, Romania

10 Biotechnology Research Center, University of Agricultural Sciences and Veterinary Medicine, RO-400372 Cluj-Napoca, Romania

11 Department of Otolaryngology, University of Medicine and Pharmacy "Iuliu Hatieganu", RO-400372 Cluj-Napoca, Romania; aurelia.maniu@umfcluj.ro

* Correspondence: mocan.andrei@umfcluj.ro (A.M.); mihai.cenariu@usamvcluj.ro (M.C.)

$\dagger$ These authors contributed equally to this work.

\begin{abstract}
The concern for implementing bioactive nutraceuticals in antioxidant-related therapies is of great importance for skin homeostasis in benign or malignant diseases. In order to elucidate some novel insights of Lycium barbarum (Goji berry) activity on skin cells, the present study focused on its active compound zeaxanthin. By targeting the stemness markers CD44 and CD105, with deep implications in skin oxidative stress mechanisms, we revealed, for the first time, selectivity in zeaxanthin activity. When applied in vitro on BJ human fibroblast cell line versus the A375 malignant melanoma cells, despite the moderate cytotoxicity, the zeaxanthin-rich extracts $\mathbf{1}$ and 2 were able to downregulate significantly the CD44 and CD105 membrane expression and extracellular secretion in A375, and to upregulate them in BJ cells. At mechanistic level, the present study is the first to demonstrate that the zeaxanthin-rich Goji extracts are able to influence selectively the mitogen-activated protein kinases (MAPK): ERK, JNK and p38 in normal BJ versus tumor-derived A375 skin cells. These results point out towards the applications of zeaxanthin from L. barbarum as a cytoprotective agent in normal skin and raises questions about its use as an antitumor prodrug alone or in combination with standard therapy.
\end{abstract}

Keywords: zeaxanthin; Goji; normal fibroblast; malignant melanoma; CD105; CD44; MAPK; ERK; JNK; p38 


\section{Introduction}

Food intake of bioactive antioxidant nutraceuticals enables skin cells protection and it influences malignant epithelial tumor growth. The concern for implementing nutraceuticals in antioxidant-related therapies is of great importance in prevention of skin homeostasis instability and occurrence of malignant illness. Many antioxidants extracted from natural sources are suitable for topical applications against various skin disorders, and beyond the topical applications, the natural extracts intake as from food can maintain the skin health condition. Over 700 carotenoids can be found in nature but only few of them have nutritional value and are present in the human body: the provitamin A carotenoids (e.g., $\beta$-carotene) and the non-provitamin A carotenoids (lycopene, zeaxanthin and its stereoisomer lutein). The antioxidant carotenoids zeaxanthin and lutein are xanthophylls, lipophilic pigments derived mainly from plant sources in the diet which the human body cannot synthesize [1]. They have free hydroxyl groups at each end of the molecule that provide unique biochemical properties that allow them to orient within cell membranes [2], quenching singlet molecular oxygen and other reactive oxygen species (ROS) [3]. Zeaxanthin supplementations provide health benefits to normal skin by modulating the expression of several genes [4] and fight against the formation of ROS [5], acting as filters for UV light exposure by accumulation in high concentrations in skin tissue. Instead, the melanoma cells growth and migration are hindered by zeaxanthin [6]. Previous experiments [7] demonstrated that the activity of zeaxanthin at $1 \mu \mathrm{M}$ was not significantly different from the controls, but at higher concentrations it manifested a cytotoxic effect on cultured human uveal melanoma cells $(3-10 \mu \mathrm{M})$ and respectively on BJ cells proliferation $(100-300 \mu \mathrm{M})$. Zeaxanthin at high dosage of $10.0 \mu \mathrm{M}$ lowered NF- $\mathrm{k} \beta$ levels due to the inhibition of NF$\mathrm{k} \beta$ pathway in uveal melanoma cells [7].

Goji berries (Lycium barbarum, Solanaceae), a traditional Asian food and medicine, are a rich source of zeaxanthin. L. barbarum became very popular during the past two decades due to its proven nourishing value, anti-inflammatory and antiaging effects, and its important role in prevention and cure of various chronical diseases. Goji berries contain many nutrients with high biological activity, such as carotenoids $(0.03 \%-0.5 \%$ of the dry matter, with zeaxanthin dipalmitate representing up to $80 \%$ of the total carotenoid), polysaccharide complexes ( $5 \%-8 \%$ of the total dry matter of the fruits), phenylpropanoids, flavonoid fractions, vitamins and fatty acids [8]. Goji antioxidative activity is mainly attributed to its carotenoid content [8,9]. Many research studies demonstrated L. barbarum extracts immunomodulation [10,11], antitumor activity [12-14] and skin protection from UV radiation [15]. The clinical efficacy of Goji berry is not yet established but its pharmaceutical properties in vitro and in vivo suggest that it may be beneficial in the prevention and treatment of tumors [16]. Carotenoids from L. barbarum fruits are associated with the extracts antitumor effect [17]. The anti-inflammatory effect was tested on mice that consumed L. barbarum juice, and the results showed a significant effect on basal and stimulated cytokine production $[18,19]$ In human skin, L. barbarum has the ability to influence the matrix metalloproteinase, which can lead to the tissues protection [20].

The mitogen activated protein kinase (MAPK) family is composed of three types of protein kinases: extracellular responsive kinase (ERK), the stress-activated c-Jun N-terminal kinases (JNK) and p38 kinase family. The three types of MAPK implicated in the control of apoptosis and their interaction, mainly a balance between ERK and the activity of stress kinases, may dictate if a cell will survive or undertake death pathways [21]. In dermal fibroblasts, zeaxanthin is able to modulate the intracellular expression of MAP kinases such Erk $1 / 2$ of p38 [6]. The in vivo experiment performed by Xiao J. et al. [22] on the influence of zeaxanthin dipalmitate on fatty liver diseases of rats demonstrated expressional changes of key MAPK members: p38, MAPK and ERK1/ 2 including modulation of NF-k $\beta$ activity, but had no influence on JNK. They concluded that treatment with zeaxanthin expressed hepatoprotective, anti-inflammatory, anti-oxidative and anti-apoptotic properties. Conversely, the non-kinase mediated pathways are likewise important in melanoma cells progression, such the non-kinase membrane glycoprotein CD44 activation [23]. The mesenchymal membrane 
marker CD44 and the adhesion-related protein CD105 (or endoglin) are important markers of stemness in skin-derived fibroblasts and in melanoma cells [24-26]; the malignant melanoma is abundant in CD44 and CD105, including the melanoma-initiating cells [27], which confer aggressivity to the tumor growth. CD44 regulates the migration of fibroblast and can enhance as well abnormal epidermal function and melanoma development [28]. The crosstalk of the two adhesion molecules CD44 and CD105 with the MAPK pathway has been proven [29].

When Goji berries' biologic effect was studied in normal skin or melanoma, generally in the spotlight were nutrients such polysaccharides, and only rarely zeaxanthin or its palmitate [30]. Meanwhile, for Lycium barbarum-derived polysaccharides, several molecular targets were already identified [31]; the mechanisms of action attributed to zeaxanthin isolated from the same extracts is unknown.

The bioavailability of zeaxanthin from food intake is dependent on its metabolism, including the esterification, and this process influences the accumulation of zeaxanthin in eyes, liver, intestines, blood vessels and in skin [1]. Several data strongly suggest that zeaxanthin supplementations may have a protective role in normal skin [1]; further, there are a few studies that address L. barbarum/Goji berries' biologic outcome on malignant melanoma of skin. Huang and co-workers (2014), in a comprehensive paper, studied another Lycium variety (L. chinense) and the chosen biologic system was a murine melanoma cell line, not a human one. There are many pending questions [1] that have led us to study the mechanisms which underlie to the effect of zeaxanthin and its metabolites in the human skin.

Therefore, in the present paper, we proposed to study the effect of zeaxanthin-rich extract from two distinct Lycium barbarum (Goji berry) varieties: Erma (1) and Biglifeberry (2), and to elucidate if they act selectively against normal skin cells versus malignant melanoma-derived cells. For the remainder of the manuscript, the term extract 1 or 2 will be employed when referring to zeaxanthin-rich Goji berry extracts Erma (1) and Biglifeberry (2).

Cytotoxicity of extracts $\mathbf{1}$ and $\mathbf{2}$ was measured, as well as the capacity of $\mathbf{1}$ and $\mathbf{2}$ to modulate the cells reducing potential and the NF-k $\beta$ transcription factor. The effect of 1 and 2 on CD44 and CD105 expression was assessed at unicellular level; these results were validated through the assessment of the treated cells extracellular secretory function. At the mechanistic level, the present manuscript presents the novelty by highlighting the Goji-derived zeaxanthin effects on the ROS-signal mediator protein kinases ERK, JNK and p38 in parallel in melanoma cells and normal fibroblasts. To elucidate new targets of carotenoid-rich Goji extracts, we focused on CD44 and CD105 membrane markers, two molecules expressed on human dermal fibroblasts and as well on melanoma cells, with deep implications in redox signaling and stemness.

\section{Materials and Methods}

\subsection{Plant Material}

Goji "Erma" and "Biglifeberry" and are two varieties of Lycium barbarum, known for their high antioxidant content. Fruits of L. barbarum L. from two cultivars were collected in the summer of 2014 from two origins: cultivar Erma (1) was collected from an ecological culture in North-Vest Romania, Ciuperceni $\left(47^{\circ} 52^{\prime} 14^{\prime \prime} \mathrm{N}, 23^{\circ} 0^{\prime} 55^{\prime \prime} \mathrm{E}\right)$, Satu-Mare County; cultivar Biglifeberry (2) was collected from an ecological culture in NV Romania, Ploscos, $\left(46^{\circ} 38^{\prime} 33^{\prime \prime} \mathrm{N}, 23^{\circ} 50^{\prime} 43^{\prime \prime} \mathrm{E}\right)$, Cluj County [32]. The fruit were harvested at full maturity and stored at $-20^{\circ} \mathrm{C}$ until analysis.

\subsection{Isolation of Carotenoids from L. barbarum Varieties Erma and Biglifeberry}

Frozen Goji berries (20 g) were homogenized with $2 \mathrm{~g}$ of sodium bicarbonate and repeatedly extracted with methanol/ethyl acetate/petroleum ether $(1: 1: 1, v / v / v$ to color exhaustion) [33]. The combined extracts were partitioned in a separation funnel with water, diethyl ether and saturated saline solution. The organic phase (diethyl ether and ethyl 
acetate) containing the pigments was filtered through anhydrous sodium sulphate and evaporated to dryness at $35^{\circ} \mathrm{C}$ under vacuum, using a rotatory evaporator. The residue was dissolved in diethyl ether. A part of the total carotenoid extract was evaporated to dry (unsaponified extract) and another part was saponified with an equal volume of potassium hydroxide solution ( $30 \%$ in methanol), at room temperature for $5 \mathrm{~h}$, under dimmed light [34]. The saponified extract was transferred into a separation funnel containing diethyl ether and washed with water until free of alkali. The solvent was completely evaporated and the saponified dry extract was further used for cell culture treatment. Fractions of both dry extracts (saponified and unsaponified) were dissolved in HPLC grade ethyl acetate and filtered through a $0.2 \mu \mathrm{m}$ PTFE filter into amber glass for HPLC analysis. All experiments were performed under subdued light.

\subsection{Cell Lines}

The human normal fibroblast cell line was BJ HEP (code CRL-2522), from American Type Culture Collection (ATCC) acquired through LGC Standards GmbH, Wesel, Germany. The cells were cultivated in Eagle's Minimal Essential Medium (MEM), supplemented with $10 \%$ fetal calf serum (FCS). The malignant melanoma cell line, A375 was from European Collection of Authenticated Cell Cultures (ECACC), through Sigma Aldrich Company, St. Louis, MO, USA. A375 cell line was cultivated in Dulbecco's Modified Eagle's medium (DMEM), supplemented as well with $10 \%$ FCS. All media and supplements were from Sigma Aldrich Company. The general instrumentation for in vitro testing were: Class II laminary hoods Lamil Plus 13 from Karstulan Metalli Oy, Karstula, Finland; 32R centrifuge with spin-out rotor from Hettich Lab Technology, Tuttlingen, Germany; Observer D.1 inverted phase fluorescence microscope from Carl Zeiss (Jena, Germany); Heto Ultrafreezer (Heto Holten, Allerd, Denmark), Cryosystem 2000 liquid nitrogen locator (MVE BioMedical Division, Burnsville, MN, USA).

\subsection{Cytotoxicity Testing}

To measure the zeaxanthin-rich Goji extracts' biologic effects, the dilution of the dried saponified extracts was made with tetrahydrofuran (THF p.a, from Merck, Darmstadt, Germany). The concentration of $\mathbf{1}$ and $\mathbf{2}$ was normalized to obtain a stock solution of $10 \mathrm{mM}$ zeaxanthin. Serial dilutions were made in phosphate buffered saline solution (PBS, from Sigma Aldrich) to obtain 2.5 to $250 \mu \mathrm{M}$ final concentration in the cell culture media, considering that in each well were added $2 \times 10^{4}$ cells in $190 \mu \mathrm{L}$ cell culture media and $10 \mu \mathrm{L}$ compound. Three separate wells were treated with each concentration on each cell line. The experiments were repeated three times. The untreated, reference wells were treated with PBS only.

The cytotoxicity of $\mathbf{1}$ and $\mathbf{2}$ was measured in triplicate, as described before [35], using the MTT dye (3-(4,5-dimethylthiazol-2-yl)-2,5-diphenyltetrazolium bromide, from Sigma Aldrich), which is transformed into its insoluble formazan form by the mitochondrial oxidoreductase enzymes, only in viable cells. The formazan crystals were solubilized in dimethyl sulfoxide (from Titolchimica, Pontecchio Polesine, Italy), and the 96-well plates were measured in colorimetry using a Synergy 2.0 microplate reader (from BioTek Company, Winooski, VT, USA) at $570 \mathrm{~nm}$ wavelength. The absorbance of each well reflects the number of viable cells present at the moment of the measurement.

\subsection{Antiproliferative Capacity}

The quantitative evaluation of $\mathbf{1}$ and $\mathbf{2}$ antiproliferative capacity was made using the Alamar Blue Cell Viability Reagent (from Molecular Probes, Eugene, OR, USA, acquired through Thermo Scientific Company), an indicator that uses the natural reducing power of living cells to convert resazurin to its fluorescent resorufin form. Following an earlier described method [36], we measured the dynamics of changes in reducing potential; three different time points were studied: 6-, 12- and 24-h, and each separate plate was processed. The BJ and A375 cells were plated on black Costar 96-well plates with clear bottom (from 
Corning BV, Amsterdam, Netherlands), at a $2 \times 10^{4}$ cell/well density in $95 \mu \mathrm{L}$ media. The adhered cells were treated with $5 \mu \mathrm{L}$ of $\mathbf{1}$ and $\mathbf{2}$, the same concentrations as for the MTT test. Three separate wells were treated with the same concentration for each compound. After the incubation, Alamar Blue reagent was added to each well and fluorescence was measured at $620 \mathrm{~nm}$ wavelength (excitation at $540 \mathrm{~nm}$ ) using the Synergy 2.0 reader. Two independent experiments were made on both cell lines.

\subsection{Flow-Cytometry Measurements of Membrane and Intracellular Markers}

To identify the membrane markers, anti-human FITC conjugated anti-CD44 and antiCD105 antibodies were used, both from Miltenyi Biotech (Bergisch Gladbach, Germany). The BJ and A375 cells were plated on 6-well plates $\left(2.5 \times 10^{5}\right.$ cells $/ 3 \mathrm{~mL}$ cell culture media), treated for $24 \mathrm{~h}$ with $\mathbf{1}$ and 2 at a subcytotoxic concentration of $50 \mu \mathrm{M}$, all samples in duplicates. As reference, untreated cells were growth in the same conditions; instead of Goji extracts, sterile PBS was added to these wells. The cells were harvested, washed with CellWash buffer (from BD Biosciences, San Jose, CA, USA), and $5 \times 10^{5}$ cells were re-suspended in $80 \mu \mathrm{L}$ PBS with $0.5 \%$ FCS. The appropriate amount of antibodies was added, according to the manufacturer's indication, the cell suspensions were incubated, washed and prepared for flow-cytometry measurement, as described earlier [37].

To evaluate the intracellular protein expression, we used the goat anti-human p65 NF-k $\beta$ antibody (acquired from R\&D Systems Europe Ltd., Abingdon, UK) with the appropriate PE anti-goat secondary antibody; goat anti-human phosphorilated ERK1+ERK2 (pT202/pY204 and pT185/pY187), phospho p38 (pT180/Y182) and phosphorilated JNK1/2 (pT183/Y185) (all from Abcam, Cambridge, UK). The cells were cultivated and treated as above, and after washing with cold PBS, the cells were permeabilized using the Inside Stain kit from Miltenyi Biotech. Two independent samples were prepared for each treated cell population. The samples were analyzed by flow cytometry, with a FACS Canto II Flow cytometer (from BD Biosciences, San Jose, CA, USA) using the 488-nm, blue, aircooled, 20-mW solid state excitation laser and the 530/30 filter for FITC as well as the 585/42 filter for PE.

\subsection{Immunoenzymatic Testing (ELISA)}

The intracellular soluble NF-k $\beta$, and the extracellular, soluble CD105 and CD44 were quantitatively evaluated with the ELISA immunoenzymatic method. The BJ and A375 cells were processed as above (2.7), and separate wells were treated with $50 \mu \mathrm{M}$ solution of 1 and 2 , in duplicates, for 6-, 12- and 24-h exposure.

The cell culture supernates were harvested from each well, aliquoted and kept at $-80^{\circ} \mathrm{C}$ in an ultra freezer. After thawing, the samples were centrifuged at 10,000 rpm for $5 \mathrm{~min}$ and the supernates were used. We used the human CD105 (ab100507) and human CD44 ELISA kits (ab45912) from Abcam, Cambridge, UK, according to the manufacturers' indication. CD44 measurement: $100 \mu \mathrm{L}$ of each sample and standard solution were added to pre-treated 96-well plate with a monoclonal antibody specific for CD44. For each treatment, two separate wells were filled, using supernates derived from parallel experiments. After $1 \mathrm{~h}$ of incubation at room temperature, three washing steps were performed using the $300 \mu \mathrm{L}$ of Wash Buffer. An amount of $50 \mu \mathrm{L}$ of $1 \mathrm{X}$ Biotinylated anti-CD44 was added to each well and $30 \mathrm{~min}$ incubation at room temperature was performed. After another three washing steps with $300 \mu \mathrm{L}$ of Wash Buffer, $100 \mu \mathrm{L}$ of $1 \mathrm{X}$ Streptavidin-HRP solution was added to each well. $100 \mu \mathrm{L}$ of Chromogen TMB substrate solution was added to each well after three washing steps and the 96-well plate was incubated for $20 \mathrm{~min}$ at room temperature. An amount of $100 \mu \mathrm{L}$ of Stop Reagent were added to each well and the measurements were performed immediately at $450 \mathrm{~nm}$ with a reference wavelength of $620 \mathrm{~nm}$.

For CD105 assessment, $100 \mu \mathrm{L}$ of each sample and standard solution were added to pre-treated 96-well plate with antibody specific for Human CD105, followed by a $2.5 \mathrm{~h}$ incubation step at room temperature. Four washing steps were performed with $300 \mu \mathrm{L}$ 
of Wash Buffer. A $1 \mathrm{~h}$ incubation step, with gentle shaking at room temperature, was performed with $100 \mu \mathrm{L}$ of $1 \mathrm{X}$ Biotinylated CD105 Detection Antibody. Another four washing steps were performed. After washing, a 45 min incubation step, with gentle shaking at room temperature, was performed after adding $100 \mu \mathrm{L}$ of $1 \mathrm{X}$ HRP-Streptavidin solution. Four washing steps were performed, followed by 30 min incubation step, with gentle shaking at room temperature, with $100 \mu \mathrm{L}$ of TMB One-Step Substrate Reagent. An amount of $50 \mu \mathrm{L}$ of Stop Solution was added to each well and the measurements were performed immediately at $450 \mathrm{~nm}$.

The intracellular NF-k $\beta$ was measured for three different concentrations: $25 \mu \mathrm{M}$, $50 \mu \mathrm{M}$ and $100 \mu \mathrm{M}$ after $24 \mathrm{~h}$ exposure. The adhered cells were washed with PBS, harvested and subjected to lysis, with the cell lysis buffer provided by the assay kit (ab176647- NF-k $\beta$ p65 SimpleStep ELISA kit from Abcam). The lysates were centrifuged, the protein level from each sample was quantified with the Bradford technique, as described elsewhere [38], and the protein concentrations of ELISA samples were normalized by dilution, in order to obtain identical concentration in each probe. The protocol was carried out according to the manufacturer's indications. An amount of $50 \mu \mathrm{L}$ of each sample was added to the pretreated 96-well plate. Over each sample, in duplicate, a standard solution $50 \mu \mathrm{L}$ of antibody cocktail was added, which contains the capture antibody and the detection antibody. After $1 \mathrm{~h}$ incubation at room temperature and $200 \mathrm{rpm}$ shake, three automatic washing steps were performed using $350 \mu \mathrm{L}$ of $1 \mathrm{X}$ washing buffer. An amount of $100 \mu \mathrm{L}$ of TMB Substrate was added to the 96-well plate and a $15 \mathrm{~min}$ incubation step was performed on $200 \mathrm{rpm}$ at dark. An amount of $100 \mu \mathrm{L}$ of Stop Solution was added to each well that contains sample and standard solution and the measurement was performed at $450 \mathrm{~nm}$ on TECAN Sunrise ELISA plate reader with Magellan software (Tecan Group, Männedorf, Switzerland). The samples were in duplicates, and as reference we used untreated cells; the blank value was the cell culture media. For quantitative assessment, a standard curve was obtained from the measurements on standard NF-k $\beta$ p 65 protein provided by manufacturer, and the single concentration values were calculated.

\subsection{Data Analysis}

The experimental results were analyzed using the GraphPad Prism5 biostatistics program (from GraphPad Software, La Jolla, CA, USA).

\section{Results}

\subsection{Characterization of the Compounds through HPLC-PDA Analysis}

The analyses were carried out on Shimadzu LC20 AT high performance liquid chromatograph, with a SPDM20A diode array detector and an YMC C30 column $(250 \times 4.6 \mathrm{~mm}$; $5 \mu \mathrm{m}$ ). The mobile phases consisted in methanol/methyl-tert-butyl ether (MTBE)/water $(81: 15: 4, v / v / v)$ (solvent A) and MTBE/methanol/water (90:7:3, $v / v / v)$ (solvent B). The gradient was as follows: $0 \mathrm{~min}, 0 \% \mathrm{~B}, 20 \mathrm{~min}, 0 \% \mathrm{~B} ; 130 \mathrm{~min}, 82 \% \mathrm{~B} ; 132 \mathrm{~min}, 0 \% \mathrm{~B}$, followed by equilibration of column for $10 \mathrm{~min}$. The flow rate was fixed at $0.8 \mathrm{~mL} / \mathrm{min}$ and the DAD, spectra were acquired in the range 300-600 $\mathrm{nm}$ the detector being set at $450 \mathrm{~nm}$. Standard compounds zeaxanthin, $\beta$-cryptoxanthin and $\beta$-carotene were provided by ChromaDex, Los Angeles, CA, USA; zeaxanthin dipalmitate was obtained by semi synthesis and purified by HPLC in our laboratory [39]. The chromatographic data and UV-VIS spectra were compared using Shimadzu LC software. Calibration curves were made with zeaxanthin, $\beta$-cryptoxanthin and $\beta$-carotene by plotting peak area against concentration for five concentrations ranging from $1-50 \mu \mathrm{g} / \mathrm{mL}$.

Chromatographic separation of unsaponified carotenoid extract revealed the presence of zeaxanthin esters, non-esterified zeaxanthin and $\beta$-carotene. The major compound in the unsaponified extract was zeaxanthin dipalmitate (peak 5 in Supplementary File Figure S1), which represented $83.2 \%$ (1) and $88.3 \%$ (2) of total carotenoids (area percentage).

Saponified Goji extracts contained zeaxanthin as the major compound, with $90.2 \%$ (sample 1) and $91.16 \%$ (sample 2) of total carotenoids). These concentrations were taken into 
account to normalize the zeaxanthin dipalmitate concentration to $10 \mathrm{mM}$ for the biologic testing. In lower amounts were identified $\beta$-cryptoxanthin, $\beta$-carotene and neoxanthin (Figure 1). The profile and the amount of carotenoids in analyzed samples (Table 1) are in agreement with previously reported data $[32,33,40]$. The total amount of carotenoids was estimated at $25.99 \mathrm{mg} / 100 \mathrm{~g}$ FW in sample $\mathbf{1}$ and $26.27 \mathrm{mg} / 100 \mathrm{~g}$ FW in sample 2.

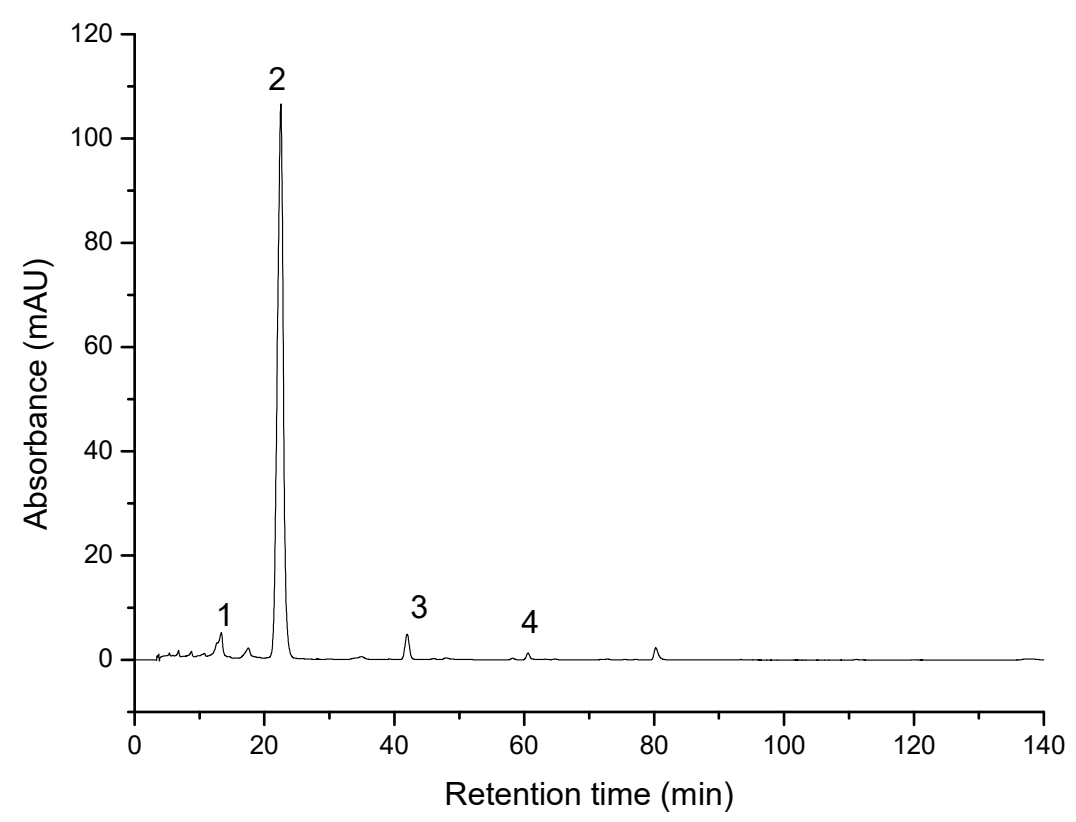

Figure 1. HPLC/PDA chromatogram of saponified Goji berries extract 2: 1-neoxanthin; 2-zeaxanthin; 3- $\beta$-cryptoxanthin; 4 - $\beta$-carotene.

Table 1. Carotenoids composition (mg/100 g FW +/ - SD) in the saponified Goji extracts.

\begin{tabular}{cccccc}
\hline ID & Compound & $\begin{array}{c}\text { Retention } \\
\text { Time }\end{array}$ & $\begin{array}{c}\text { UV-Vis } \\
\text { Maxima }\end{array}$ & $\begin{array}{c}\text { Sample 1 } \\
\text { mg/100 g FW }\end{array}$ & $\begin{array}{c}\text { Sample 2 } \\
\text { mg/100 g FW }\end{array}$ \\
\hline 1 & Neoxanthin & 14.6 & $416,439,468$ & $0.70 \pm 0.14$ & $0.75 \pm 0.16$ \\
\hline 2 & Zeaxanthin & 22.1 & $425,450,476$ & $23.44 \pm 1.02$ & $23.69 \pm 1.13$ \\
\hline 3 & $\beta$-cryptoxanthin & 41.9 & $425,451,476$ & $0.60 \pm 0.15$ & $0.49 \pm 0.14$ \\
\hline 4 & $\beta$-carotene & 60.6 & $421,452,477$ & $0.07 \pm 0.02$ & $0.07 \pm 0.02$ \\
\hline
\end{tabular}

\subsection{Evaluation of the Extracts Effect on Skin-Derived Cells Growth}

\subsubsection{Cytotoxicity}

The normal BJ fibroblasts and the A375 malignant melanoma cells were exposed for $24 \mathrm{~h}$ to the saponified Lycium barbarum (Goji) extracts $\mathbf{1}$ and 2, and their cytotoxicity was quantified (Table 2). The one-way ANOVA comparison test indicates no significant differences in $\mathrm{IC}_{50}$ values $(p<0.05)$ between 1 and 2 and the extracts cytotoxicity was comparable in BJ and A375 cell lines.

\subsubsection{The Antiproliferative Capacity}

The Alamar Blue fluorescent stain indicates the intracytoplasmic reducing capacity of the cells, implicitly their metabolic status. The comparison between the fluorescence measured in presence or absence of treatment with 1 or 2 reflects their antiproliferative capacity. For this purpose, the modulation of the reducing capacity was assessed with the same concentration range of $\mathbf{1}$ and $\mathbf{2}$ was used as for the cytotoxicity testing. The cells' exposure to zeaxanthin from Goji extracts 1 and $\mathbf{2}$ caused a decrease in fluorescence, proportionally with the concentration and the exposure time $(6,12$ or $24 \mathrm{~h}$, Figure 2, Table 2). In BJ normal cell line and A375 malignant melanoma, extract 2 exhibited antiproliferative 
activity. The activity of $\mathbf{1}$ was statistically significant in BJ cells, and in A375 after $24 \mathrm{~h}$ of treatment (Figure 2).

Table 2. The cytotoxicity of zeaxanthin-rich extracts 1 and 2 , expressed as half inhibitory concentration $\left(\mathrm{IC}_{50}\right.$, sigmoidal dose-response) and the antiproliferative capacity expressed as significant negative hillslope derived from the linear regression of time-dependent inhibition.

\begin{tabular}{|c|c|c|c|c|c|}
\hline & & \multicolumn{4}{|c|}{$\mathrm{IC}_{50}$ Values $(\mu \mathrm{M})$} \\
\hline Cell Line & & \multicolumn{2}{|c|}{ BJ (CRL-2522) } & \multicolumn{2}{|c|}{ A375 } \\
\hline 1 & $24 \mathrm{~h}$ & \multicolumn{2}{|c|}{$75.15 \pm 0.23$} & \multicolumn{2}{|c|}{$62.36 \pm 0.08$} \\
\hline \multirow[t]{2}{*}{2} & $24 \mathrm{~h}$ & $85.06=$ & & $92.59 \pm$ & \\
\hline & & \multicolumn{4}{|c|}{ Inhibition of Proliferation } \\
\hline \multirow[t]{2}{*}{ Cell line } & & \multicolumn{2}{|c|}{ BJ (CRL-2522) } & \multicolumn{2}{|c|}{ A375 } \\
\hline & & Hillslope & $p$ value & Hillslope & $p$ value \\
\hline \multirow[t]{3}{*}{1} & $6 \mathrm{~h}$ & $-4726 \pm 905.0$ & 0.0002 & $459.6 \pm 228.7$ & 0.0675 \\
\hline & $12 \mathrm{~h}$ & $-4274 \pm 822.5$ & 0.0002 & $389.2 \pm 301.3$ & 0.2208 \\
\hline & $24 \mathrm{~h}$ & $-2754 \pm 606.8$ & 0.0007 & $-654.8 \pm 182.8$ & 0.0038 \\
\hline \multirow[t]{3}{*}{2} & $6 \mathrm{~h}$ & $-4179 \pm 877.0$ & 0.0005 & $-3166 \pm 576.8$ & 0.0001 \\
\hline & $12 \mathrm{~h}$ & $-3706 \pm 807.5$ & 0.0006 & $-3076 \pm 482.9$ & $<0.0001$ \\
\hline & $24 \mathrm{~h}$ & $-2253 \pm 582.5$ & 0.0022 & $-2109 \pm 345.0$ & $<0.0001$ \\
\hline
\end{tabular}
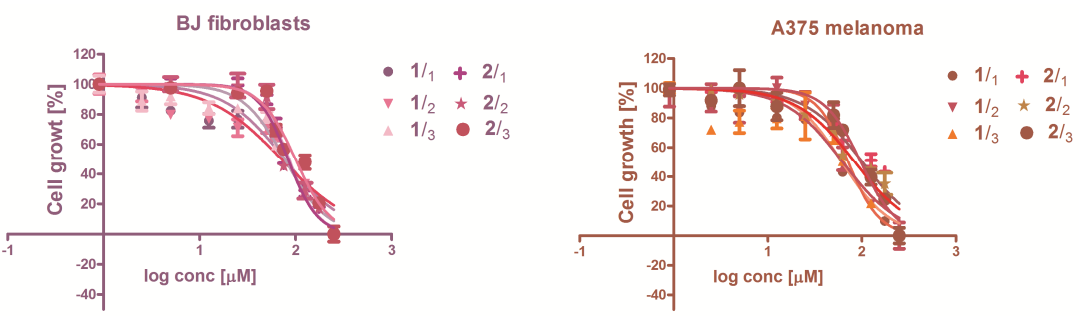

(a)
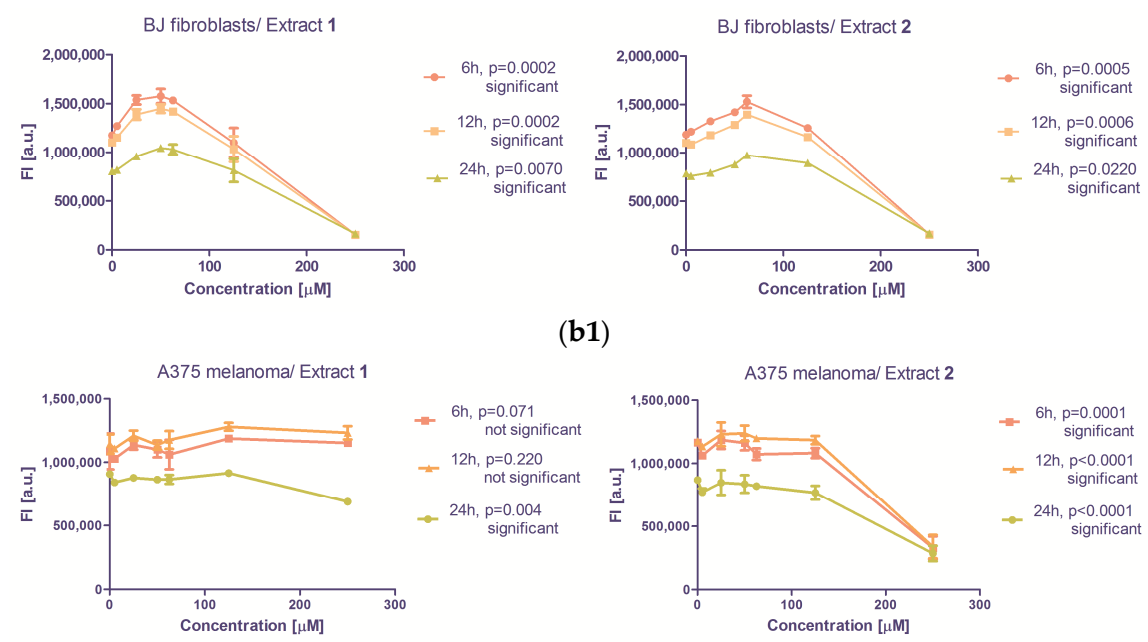

(b1)

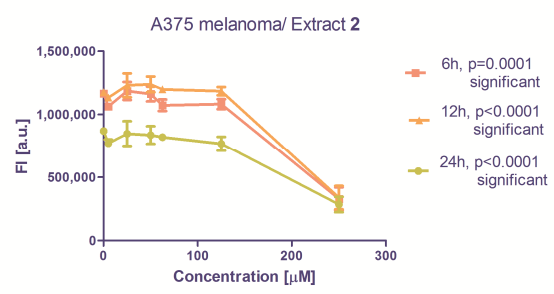

(b2)

Figure 2. The in vitro effect of zeaxanthin-rich Goji extracts $\mathbf{1}$ and $\mathbf{2}$ on the cells survival, and proliferation; (a) sigmoidal dose-response relationship between the concentration of 1 and 2 and the inhibition of the cells growth during $24 \mathrm{~h}$ of exposure; $(\mathbf{b} 1, \mathbf{b} 2)$ linear dose-response relationship between the compounds concentration and metabolic activity-related Alamar Blue fluorescence (FI on y axis is the fluorescence intensity). 
The capacity of zeaxanthin from Goji extract to modulate the intracellular reducing potential in treated normal fibroblasts (BJ) and malignant melanoma (A375) population, quantified by linear regression in the $95 \%$ confidence interval (Figure 2). The statistical significance of the deviation from untreated cells, considered as concentration 0 , was quantified using the hill slope, $\mathrm{p}$ being the quantification of the probability. The linear regression in the $95 \%$ confidence interval indicates significant decrease following the treatment, exception being the shorter, 6- or 12-h exposure of A375 cells. Considering that the Lycium barbarum extracts contain other bioactive compounds as well [41], and the different Goji cultivars display various phenolic patterns [42], they can influence $\mathbf{1}$ and $\mathbf{2}$ biologic activity even if the other phenols distribution in $\mathbf{1}$ and $\mathbf{2}$ is reduced in comparison with the zeaxanthin.

\subsection{The Extracts 1 and 2 Effect on CD44 and CD105 Markers}

The expression of CD44 membrane marker was abundant on BJ fibroblasts surface $(89.51 \%)$, and the $24 \mathrm{~h}$ exposure to Goji-derived zeaxanthin $\mathbf{1}$ and $\mathbf{2}$ generated a slight increase $(93.82 \%$ and $93.52 \%$, correspondingly, Figure 3 and Table 3). In A375 cells, the untreated reference values were lower, but still $50.13 \%$ of the cells were CD44-positive, which decreased significantly (two-way analysis of variance in the $95 \%$ confidence interval) following the cells exposure to $\mathbf{1}$ (to $33.35 \%$ ) and $\mathbf{2}$ (to $32.16 \%$ ). The 24-h exposure to $\mathbf{1}$ and 2 augmented the secreted CD44 level in A375 cells, dissimilar to the shorter exposures: $6 \mathrm{~h}$ and $12 \mathrm{~h}$ give inconsistent or statistically insignificant changes. In BJ, only extract 2 was capable to increase the secreted CD44 level, after $24 \mathrm{~h}$ exposure (Figure 3), while none of the other exposure lengths was sufficient to significantly modulate CD44 secretion (one-way analysis of variances in the $95 \%$ interval).

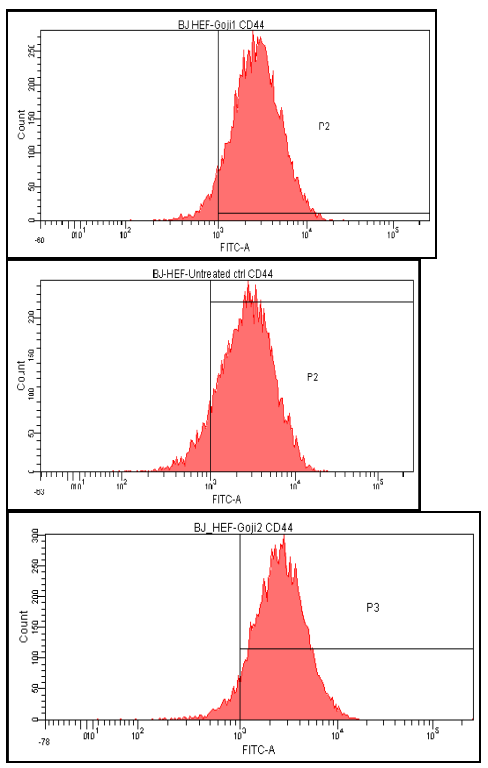

(a)

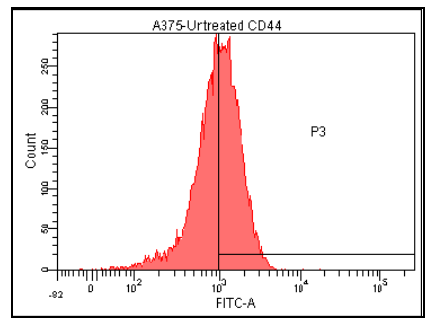

Figure 3. Cont. 


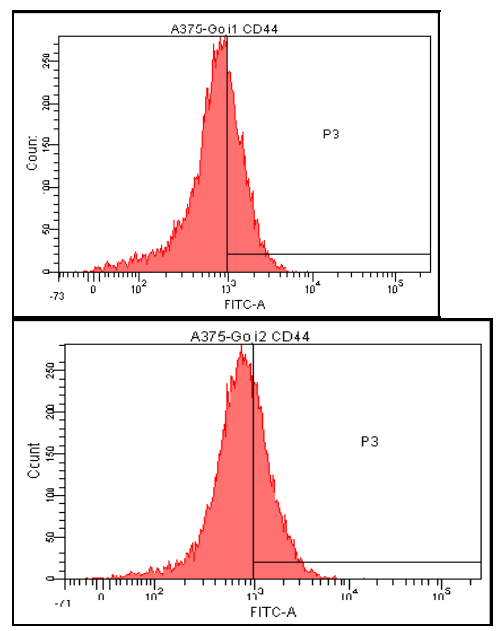

(b)

BJ

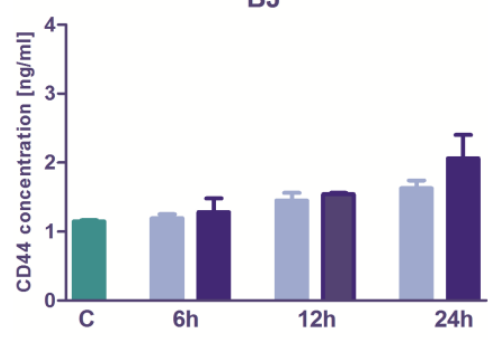

Figure 3. The modulation of CD44 membrane marker expression and the level of secreted CD44 protein in normal BJ versus A375 tumor cells treated with zeaxanthin-rich extract from Goji berries in vitro. The histograms represent the distribution of CD44-positive BJ cells (a) and CD44-positive A375 cells (b) in untreated control versus treatment with $50 \mu \mathrm{M}$ zeaxanthin-rich extract $\mathbf{1}$ and 2, respectively. In the lower row (c): the level of secreted CD44 protein by the normal BJ and malignant A375 cells following the same treatments; the columns correspond to the untreated control $\mathrm{C}$ and zeaxanthin-rich extracts 1 and 2.

Table 3. Regulation of membrane- and intracellular marker expression in tumor and normal cells in vitro by the treatment with Goji-derived zeaxanthin 1 and 2.

\begin{tabular}{|c|c|c|c|c|c|c|}
\hline Cells and Treatments & CD44 & CD105 & NF-k $\beta$ & JNK & p38 & ERK \\
\hline \multicolumn{7}{|l|}{ A375 } \\
\hline Untreated & $50.1 \pm 0.40$ & $4.0 \pm 0.02$ & $5.8 \pm 0.05$ & $14.3 \pm 0.03$ & $14.1 \pm 0.01$ & $29.2 \pm 0.11$ \\
\hline Extract 1 & $33.4 \pm 0.16$ & $2.7 \pm 0.01$ & $14.6 \pm 0.02$ & $30.7 \pm 0.05$ & $19.4 \pm 0.08$ & $34.5 \pm 0.14$ \\
\hline Extract 2 & $32.2 \pm 0.18$ & $2.0 \pm 0.00$ & $18.5 \pm 0.12$ & $29.3 \pm 0.15$ & $20.0 \pm 0.04$ & $42.4 \pm 0.27$ \\
\hline \multicolumn{7}{|l|}{ BJ } \\
\hline Untreated & $89.5 \pm 0.10$ & $18.8 \pm 0.03$ & $0.02 \pm 0.00$ & $40.0 \pm 0.14$ & $35.4 \pm 0.25$ & $30.9 \pm 0.13$ \\
\hline Extract 1 & $93.8 \pm 0.02$ & $13.7 \pm 0.12$ & $0.01 \pm 0.00$ & $27.4 \pm 0.05$ & $32.3 \pm 0.04$ & $25.9 \pm 0.07$ \\
\hline Extract 2 & $93.5 \pm 0.05$ & $17.7 \pm 0.07$ & $0.05 \pm 0.00$ & $43.7 \pm 0.11$ & $25.4 \pm 0.02$ & $25.1 \pm 0.06$ \\
\hline
\end{tabular}

The influence of $\mathbf{1}$ and $\mathbf{2}$ on CD105-positive cells proportion was less significant (Figure 4). In A375 cells, the CD105 basal value was low (3.99\%) and the action of extracts caused insignificant decrease (to 2.70 following $\mathbf{1}$ and 1.97 following 2 activities). In BJ 
cells, zeaxanthin 1 solution caused a decrease: from basal $18.83 \%$ to $13.72 \%$, while the effect of 2 has had no significance on CD105 marker (17.73\%). The cells in vitro CD105 secretor capacity was evaluated with Elisa testing (Figure 4); the A375 melanoma cells CD105 level was significantly higher that of BJ normal fibroblasts, the result being in concordance with previously published data [43]. Extract $\mathbf{2}$ showed selectivity, acting more efficiently on melanoma cells membranar CD105 (one-way ANOVA, Bonferroni post test, $p<0.05$ ) and more, it has had the capacity to stimulate the CD105 production in fibroblast (Figure 4), contrary with the diminishing effect in A375 melanoma.

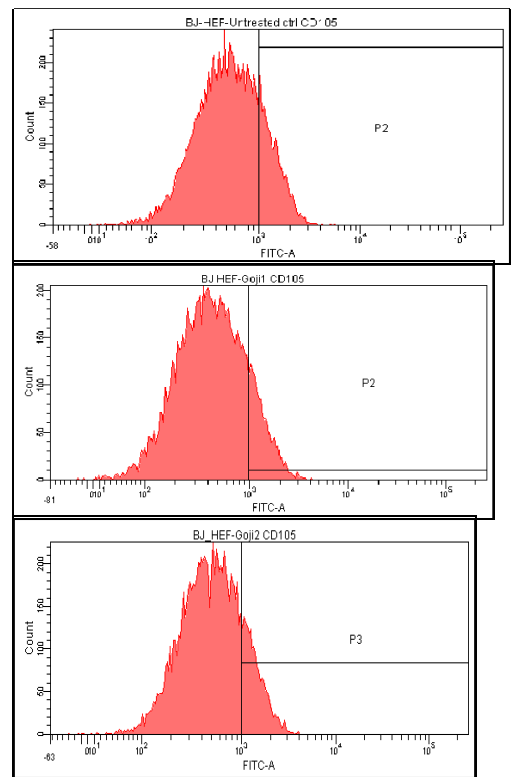

(a)

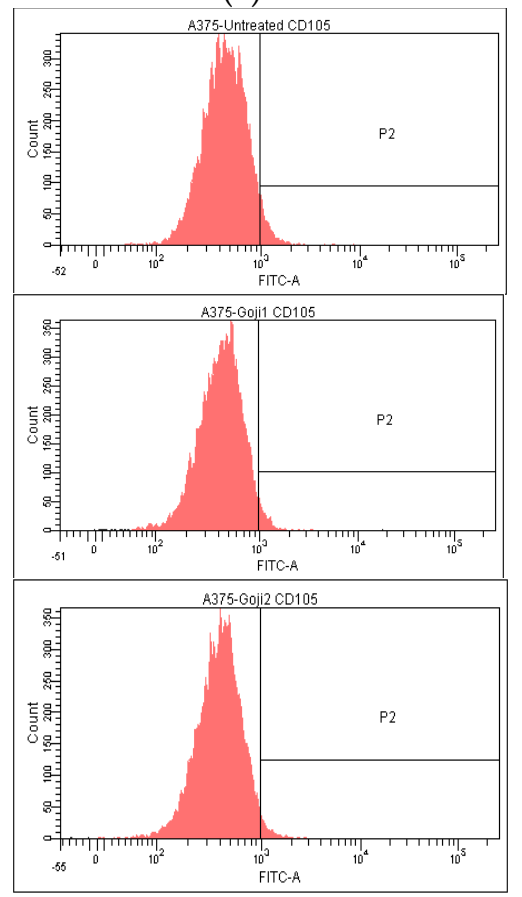

(b)

Figure 4. Cont. 

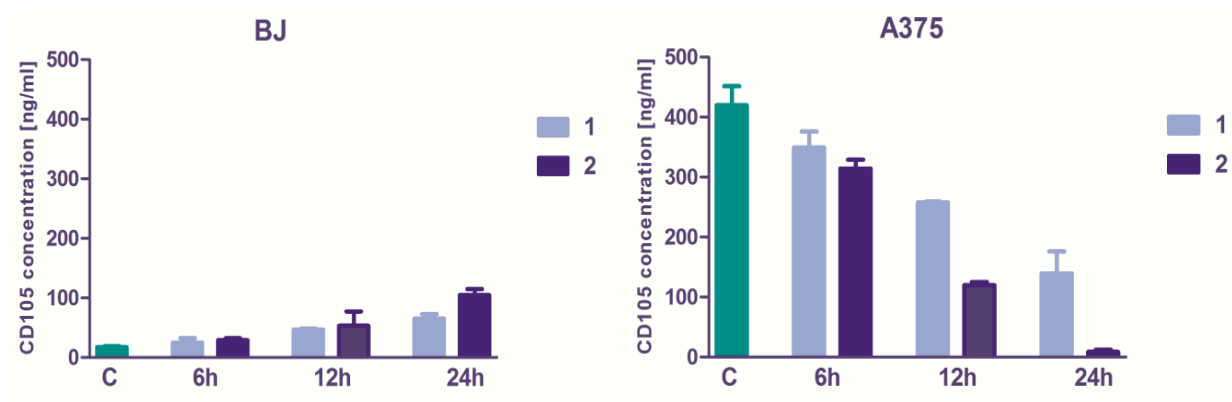

(c)

Figure 4. The zeaxanthin-rich extract 1 and 2 influence on CD105 membrane marker expression in normal BJ (a) and A375 melanoma cells (b). From top down: untreated cells and cells treated for $24 \mathrm{~h}$ with $50 \mu \mathrm{M}$ extracts 1 or $\mathbf{2}$. In the lower row (c) the secreted soluble CD105 levels are represented in $\mathrm{BJ}$ and A375 cells, following the treatment with $\mathbf{1}$ or $\mathbf{2}$, at the same concentration.

\subsection{The Evaluation of NF- $k \beta$ Transcription Factor}

The soluble form of total p65 NF-k $\beta$ was quantified immunoenzymatically with the ELISA testing. The basal values were lower in fibroblasts than in melanoma cells, and the variations in intercellular NF- $\mathrm{k} \beta$ concentration were not dose-dependent in BJ cells, although a clear tendency of NF-k $\beta$ drop was observed, opposite to A375 cells where $50 \mu \mathrm{M}$ subcytotoxic and $100 \mu \mathrm{M}$ cytotoxic concentrations both conducted to NF-k $\beta$ increase (Figure 5). The flow cytometry showed that the expression of intracytoplasmic phosphorylated form of NF-k $\beta$ in BJ cells was nearly zero, and the treatment with $50 \mu \mathrm{M}$ $\mathbf{1}$ or $\mathbf{2}$ does not influenced this molecule. Instead, in A375 cells, the basal activation was higher (Figure 5), which is in concordance with previous findings [44] and the extracts caused a significant increase in NF-k $\beta$ : $14.60 \%$ versus $5.75 \%$ for $\mathbf{1}$ and $18.50 \%$ versus $5.75 \%$ for $\mathbf{2}$, the tendency of increase being correlated with the soluble NF-k $\beta$ for the same treatment (Spearman nonparametric correlation, $\mathrm{r} 0.94, p$ value 0.0083 , very significant).

\subsection{Modulation of MAPK Signaling}

The intracellular MAP kinases signaling were analyzed through flow cytometry, which allowed to quantify the positive cells in treated BJ and A375 populations. Based on the quantitative measurement of the intracellular MAP-kinases JNK, p38 and ERK (Table 3) the percent of up- or down-regulation of the three markers was calculated (Table 4), relative to the untreated cells. In the A375 melanoma, both $\mathbf{1}$ and $\mathbf{2}$ zeaxanthin-rich extracts triggered up-regulation of phosphorilated JNK 1/2, ERK1 + ERK2 and p38, while in BJ cells, in most of the cases, the negative values point toward the three intracellular MAP kinases suppression, with one exception: following the exposure to 2, JNK increased to some extent in compare with the untreated reference.

In normal BJ fibroblasts, the JNK, ERK and p38 expression was downregulated (Table 4). After the treatment, less positive cells were observed in both BJ and A375; it was a single exception: following the action of zeaxanthin 2, JNK expression increased with 9.12 percent $(40.04 \%$ of positive untreated cells versus $43.69 \%$ after 24 -h incubation with 2). The largest extent of downregulation was generated by 1 on JNK kinase (Table 4 , Figure 6). In malignant A375 cells, the ROS signalling pathways showed a completely different outcome (Table 4), all kinases being strongly upregulated.

The strongest selectivity was observed as well in the effect of $\mathbf{1}$ on JNK, the difference between the normal and tumor cells being $146.08 \%$ (Figure 6). The distribution of p38positive cells (Table 4, Figure 7) and the ERK-positive cells (Figure 8) following the 24-h exposure to Goji extracts $\mathbf{1}$ and $\mathbf{2}$ showed similarities: in both cases, the percent of positive cells augmented significantly (one-way ANOVA test, $p<0.05$ ) in A375 tumor cells, while in normal BJ cells the expression of ERK and p38 was suppressed. 


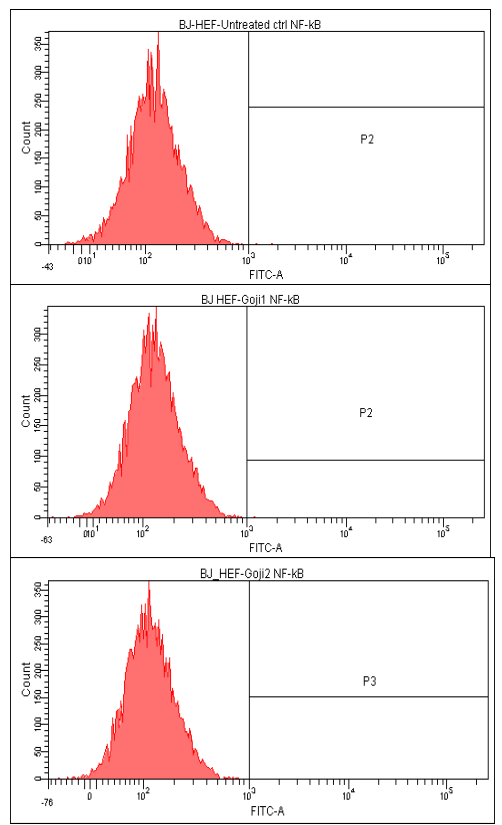

(a)

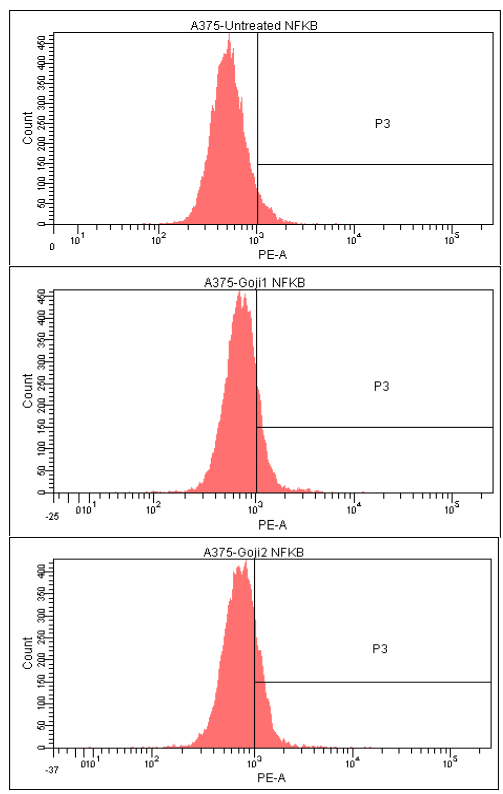

(b)
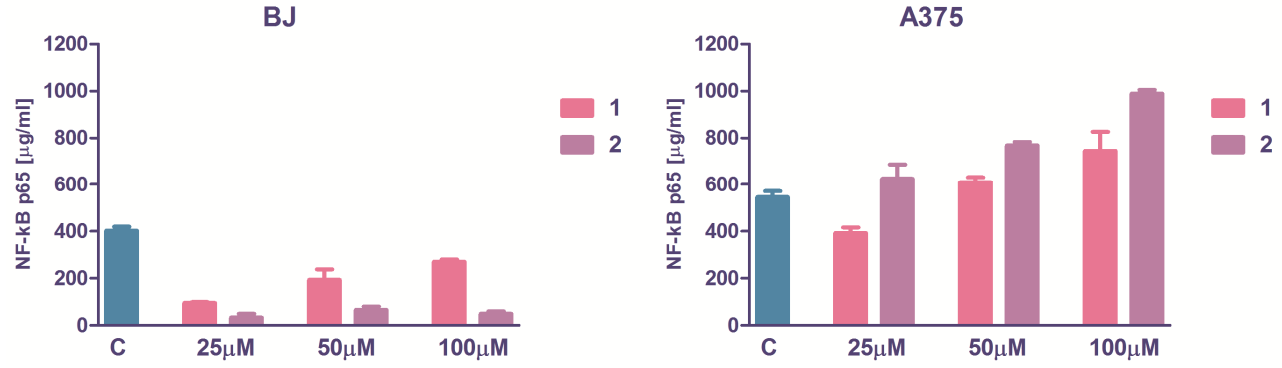

(c)

Figure 5. The zeaxanthin-rich extracts influence on intracellular transcription factor NF-k $\beta$ p65 is depicted by flowcytometry generated histograms of normal BJ (a) and malignant A375 cells (b) subjected to a 24-h treatment; from left to right: untreated cells, treatment with $50 \mu \mathrm{M} 1$ and 2. (c) The dose-response relationship between the quantity of zeaxanthin added to the cells and the concentration of the soluble NF-k $\beta$ p65 secreted within $24 \mathrm{~h}$. 
Table 4. The influence of zeaxanthin-rich Goji extracts 1 and $\mathbf{2}$ on phosphorilated mitogen activated protein (MAP) kinasesdriven ROS signaling upregulation (depicted as $\uparrow$ ) or downregulation (depicted as $\downarrow$ ) in normal and malignant cells in vitro.

\begin{tabular}{cccccc}
\hline \multirow{2}{*}{$\begin{array}{c}\text { Mitogen Activated Protein } \\
\text { Kinases (MAPK) }\end{array}$} & Cell Line & \multicolumn{2}{c}{ BJ } & & A375 \\
\cline { 2 - 6 } & Treatment & $\mathbf{1}$ & $\mathbf{2}$ & $\mathbf{1}$ & $\mathbf{2}$ \\
\hline JNK & & $\downarrow 31.68 \%$ & $\uparrow 9.12 \%$ & $\uparrow 114.40 \%$ & $\uparrow 104.61 \%$ \\
ERK & & $\downarrow 16.02 \%$ & $\downarrow 18.72 \%$ & $\uparrow 18.28 \%$ & $\uparrow 45.42 \%$ \\
p38 & & $\downarrow 9.00 \%$ & $\downarrow 28.41 \%$ & $\uparrow 36.75 \%$ & $\uparrow 41.63 \%$ \\
\hline
\end{tabular}
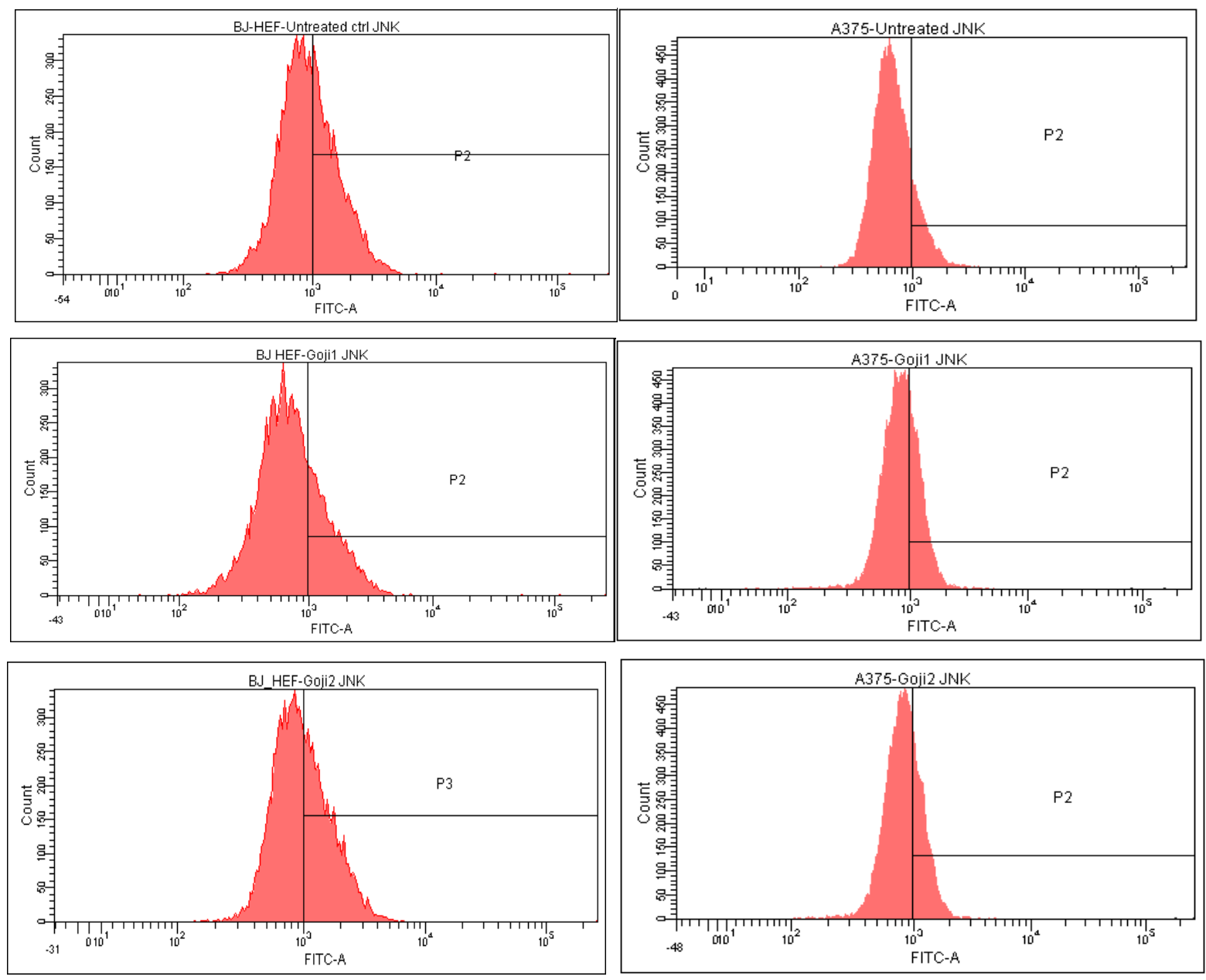

Figure 6. The intracellular c-Jun N-terminal kinases (JNK) modulation in normal BJ fibroblasts versus malignant melanoma A375 cells following the 24-h exposure to zeaxanthin. In the left column, the BJ cells are represented, while in the right column the A375 cells; from top down: cells without treatment (reference), cells treated with $\mathbf{1}$ and 2. 

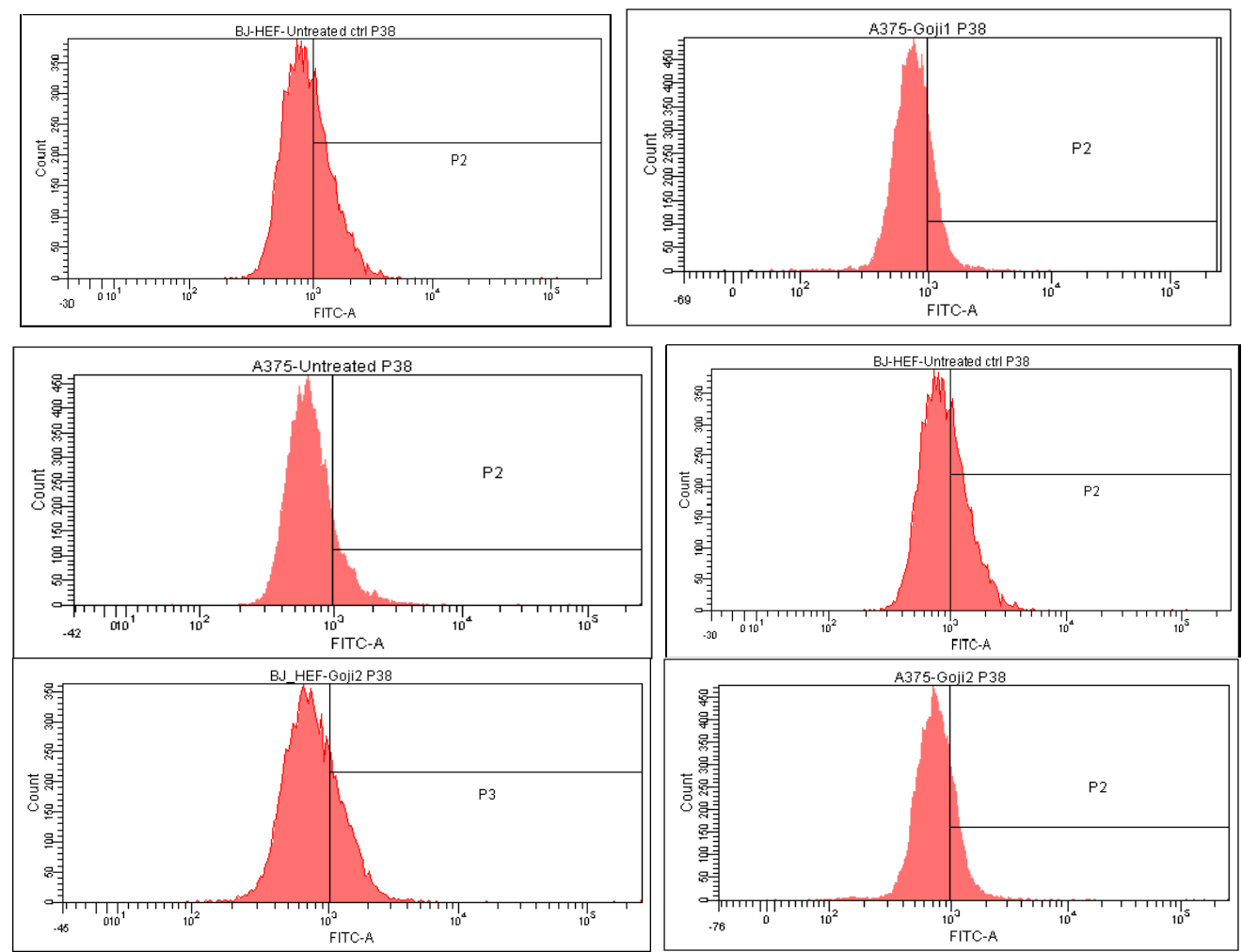

Figure 7. The intracellular p38 expression in normal BJ fibroblasts versus A375 malignant melanoma following the 24-h exposure to zeaxanthin-rich extracts 1 and 2 . In the left column are represented from top down: untreated cells, cells treated with 1, and cells treated with 2, respectively; in the right column, A375 cells, in the same order.
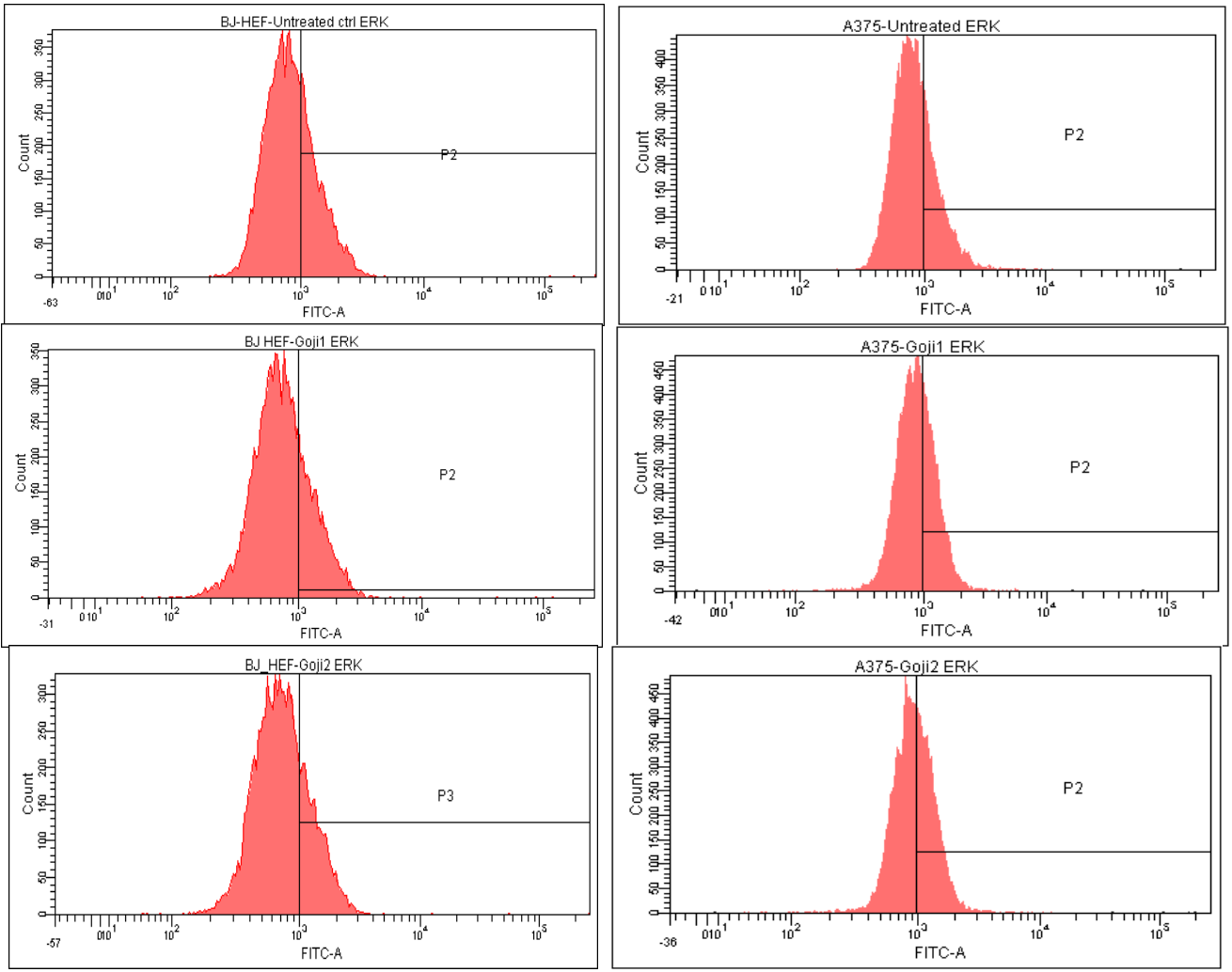

Figure 8. The extracellular signal-regulated kinase ERK 1/2 modulation in normal BJ fibroblasts (left) and A375 malignant melanoma (right) following the 24-h exposure to zeaxanthin 1 and $\mathbf{2}$. 


\section{Discussion and Conclusions}

Zeaxanthin dipalmitate was firstly identified in Goji berries by Weller and Breithaupt in 2003 [45], in a study that focused on distribution zeaxanthin esters in various fruit. According to these authors, zeaxanthin represents $89 \%$ of the total area of carotenoids (recorded at $450 \mathrm{~nm}$ ) in the saponified extract, while zeaxanthin dipalmitate was quantified at $160.9 \mathrm{mg} / 100 \mathrm{~g}$ dry material in the unsaponified extract. Later, Inbaraj et al. [36] identified also neoxanthin, $\beta$-cryptoxanthin, $\beta$-carotene and some of their geometric isomers in the saponified Goji extract. Zeaxanthin represented 1196.8 micrograms/g (89.64\% of total carotenoids) in the saponified extract, while zeaxanthin dipalmitate (1143.4 micrograms/g) represented $80.5 \%$ in the unsaponified extract. A similar profile was reported [46] for the saponified extract. Environmental factors and processing methods (drying) can affect the total amount of carotenoids in commercial Goji berries.

Zeaxanthin and lutein are xanthophylls (hydroxy carotenoids) that accumulates preferentially in the human retina where they seem to have a protective effect by acting as filter pigments or as antioxidants [47]. Zeaxanthin is present in fruit and vegetables in both free and esterified form. While corn or egg yolk are good sources of free zeaxanthin, Goji berries, sea buckthorn berries or orange pepper are rich in zeaxanthin mono- and diesters [48]. Supplementation of human subjects with Goji berries resulted in a significant increase of free zeaxanthin (but not that of esterified zeaxanthin) in plasma, demonstrating that esters are efficiently hydrolyzed and absorbed $[45,49]$. Very low concentrations of xanthophylls esters were found in plasma or human skin after long-time supplementation with high doses of esters [50,51]. Chitchumroonchokchai and Failla [52] showed that zeaxanthin esters were partially hydrolyzed by carboxyl ester lipase and free zeaxanthin was the most abundant form in Caco-2 cells. All these experimental data sustain the hypothesis of the complete hydrolysis of ester fraction during digestion and a postabsorptive acylation of xanthophylls. Considering these observations, in the present study we decided to use the saponified extract of Goji berry.

The zeaxanthin-rich extracts from Goji Erma (1) and Biglifeberry (2) inhibited at some extent the fibroblast proliferation in vitro, these results being in accordance with previous studies [7]. Zeaxanthin effect was dissimilar to those of glycoconjugates from Goji, which promoted the survival of human fibroblasts [20].

The activation of NF-k $\beta$ can be quantified evaluating the extent of its nuclear p65 subunit translocation [39]. NF-k $\beta$ act like a molecular switch in melanoma [44]. In late stages of melanoma, it is activated and inhibits the apoptosis, and is therefore associated with tumor progression; thus, in early stages, NF- $\mathrm{kB}$ upregulates the caspase-dependent apoptotic pathways. The upregulation of the NF-k $\beta$ indicates cancer progression, and many natural products were identified as blockers of this signaling pathway [39]. In the case of L. barbarum extracts 1 and 2, no inhibition of p65 intracytoplasmic translocation was observed in A375 cells (Figure 5), while in uveal melanoma the inhibition of NF-kB pathway was reported [7].

CD105 is a transforming growth factor TGF- $\beta$ co-receptor, its interaction with TGF- $\beta 1$ inhibits the TGF- $\beta$ mediated ERK signaling [53], resulting in decreased endothelial cell migration and cell adhesion, and influences the apoptosis and proliferation in many cell types, including skin cells. CD105 targeting through natural compounds such zeaxanthin could be a promising therapeutic approach for malignant melanoma [54] and the disruption of membrane endoglin can suppress the tumor progression [55]. Since zeaxanthin-rich Goji extracts 1 and $\mathbf{2}$ has had the ability to reduce both membrane CD105 and especially the soluble CD105 in malignant melanoma cells, it could be of interest in new drugs development.

Unlike previous studies, the intracytoplasmatic expression of MAP kinases was assessed with flow cytometry methods at unicellular level. In melanoma cell the ERK-, JNK- and p38-mediated signaling pathway is involved in melanin production as well [30]. Zeaxanthin-rich extracts $\mathbf{1}$ and $\mathbf{2}$ act as p38 suppressors in normal skin cells, same as other fractions extracted from L. barbarum [4]; in A375 melanoma cells, the opposite effect was observed. The three MAP kinases were significantly upregulated by $\mathbf{1}$ and $\mathbf{2}$ in A375 cells. 
The activation of JNK displays versatile effects on malignant melanoma cells. Wang and co-authors [56] reported a correlation between JNK activation and the tumor proliferation in vivo in mice, while other studies indicated that JNK activation by nutraceuticals trigger apoptosis in melanoma cells [57]. The mitogen activated protein kinases (MAPK) are therapeutic targets in cancer [58]. ERK is involved in cell survival and proliferation and can activate transcription factors such NF- $\mathrm{KB}$; therefore, the overexpression of ERK $1 / 2$ point towards the proapoptotic processes in A375 cells. The increase of phosphorilated JNK, ERK1/2 or $\mathrm{p} 38$ membrane expression could lead to an augmented pro-oxidative process inside the tumor cells, detrimental to the survival of tumor cells. Zeaxanthin was able to regulate the increase of JNK and p38 expression in gastric tumor cells through the increase of ROS levels [59], and this confirms our hypothesis. Overall, the effect of $\mathbf{1}$ and $\mathbf{2}$ on A375 melanoma cells in vitro raises questions about the opportunity of their employment as antitumor agents, and downstream effects of these pathways need to be explored as well.

The fact that $\mathbf{1}$ and $\mathbf{2}$ have had similar, but not identical, effect denotes that besides zeaxanthin, the rest of the components (under $17 \%$, and $12 \%$ in the composition of extracts) may play an important biologic role as well, and the plant cultivar marked its own biologic fingerprint on human skin cells in vitro, which can be extrapolated to in vivo effect.

Extracts 1 and $\mathbf{2}$ showed a beneficial cytoprotective effect on normal skin fibroblasts at subcytotoxic concentrations, the threshold of $50 \mu \mathrm{M}$ being optimal for in vitro applications. For a possible dietary intake of zeaxanthin or topical applications on skin, the recommended concentration has to be tested in vivo.

In vitro, the zeaxanthin-rich Goji extracts $\mathbf{1}$ and $\mathbf{2}$ have had a moderate activity against A375 melanoma cells, and there are no major differences between their toxicity on normal and tumor cells. Moreover, the JNK, ERK, p38 and the total NF-k $\beta$ were upregulated, and these results point out towards an antiapoptotic pattern, even if they are able to reduce the tumor cells growth. However, the distribution of CD44-positive and CD105-positive cells after 1 and 2 treatment clearly indicated the reduction of stemness, induction of proapoptotic signaling in melanoma cells. Therefore, we can suppose that, in vivo, $\mathbf{1}$ and $\mathbf{2}$ might be efficient alone as prodrugs but more likely as adjuvants to the standard antitumor chemotherapy, but this needs further investigation.

Supplementary Materials: Figure S1: The major compound in the unsaponified extract was zeaxanthin dipalmitate (peak 5).

Author Contributions: Conceptualization of the manuscript, D.C., E.F.-F., A.P., and A.M. (Alma Maniu); methodology, M.C., A.B., and A.M. (Andrei Mocan), P.V. and M.P.-S.; software, A.B.T. and V.-A.T.; validation, M.C., P.V., M.P.-S., and E.F.-F.; formal analysis, A.B., A.B.T., and V.-A.T.; investigation, D.C., A.B., A.M. (Andrei Mocan), A.B.T., and V.-A.T.; resources, D.C. and A.M. (Alma Maniu); data curation, D.C., E.F.-F., A.M. (Andrei Mocan), and M.C.; writing—original draft preparation, D.C., E.F.-F., P.V., A.M. (Alma Maniu), M.C., and M.P.-S.; writing-review and editing, E.F.-F., A.P., I.B.-N., G.C., and A.M. (Alma Maniu); visualization, D.C., M.C., A.M. (Alma Maniu), and A.B.; supervision, A.P., I.B.-N., and G.C. All authors have read and agreed to the published version of the manuscript.

Funding: "This paper was published under the frame of European Social Found, Human Capital Operational Programme 2014-2020, project no. POCU/380/6/13/125171" and co-funded by the Ministry of Research and Innovation, CNCS-UEFISCDI, project number PN-III-P2-2.1-PED-2019-3813, within PNCDI III.

Institutional Review Board Statement: Not applicable.

Informed Consent Statement: Not applicable.

Data Availability Statement: Not applicable.

Acknowledgments: The authors are grateful to Emeric Kolbaszer (Gojiland Romania) for providing the plant material from cultivar Erma and to Mircea Moca for providing the plant material from cultivar Biglifeberry.

Conflicts of Interest: The authors declare no conflict of interest. 
Sample Availability: Samples of the compounds are not available from the authors.

\section{References}

1. Murillo, A.G.; Hu, S.; Fernandez, M.L. Zeaxanthin: Metabolism, Properties, and Antioxidant Protection of Eyes, Heart, Liver, and Skin. Antioxidants 2019, 8, 390. [CrossRef]

2. Roberts, R.L.; Green, J.; Lewis, B. Lutein and zeaxanthin in eye and skin health. Clin. Dermatol. 2009, 27, 195-201. [CrossRef]

3. Sies, H.; Stahl, W. Non-nutritive bioactive constituents of plants: Lycopene, lutein and zeaxanthin. Int. J. Vitam. Nutr. Res. 2003, 73, 95-100. [CrossRef]

4. Li, R.; Turner, S.D.; Brautigan, D.L. Xanthophylls lutein and zeaxanthin modify gene expression and induce synthesis of hyaluronan in keratinocyte model of human skin. Biochem. Biophys. Rep. 2015, 4, 52-58. [CrossRef]

5. Schwartz, S.; Frank, E.; Gierhart, D.; Simpson, P.; Frumento, R. Zeaxanthin-based dietary supplement and topical serum improve hydration and reduce wrinkle count in female subjects. J. Cosmet. Dermatol. 2016, 15, 13-20. [CrossRef] [PubMed]

6. Wu, N.L.; Chiang, Y.C.; Huang, C.C.; Fang, J.Y.; Chen, D.F.; Hung, C.F. Zeaxanthin inhibits PDGF-BB-induced migration in human dermal fibroblasts. Exp. Dermatol. 2010, 19, e173-e181. [CrossRef]

7. Bi, M.C.; Hose, N.; Xu, C.L.; Zhang, C.; Sassoon, J.; Song, E. Nonlethal levels of zeaxanthin inhibit cell Invasion, and secretion of MMP-2 via NF- $\kappa \beta$ pathway in cultured human uveal melanoma cells. J. Ophtalmol. 2016, 2016, 8734309. [CrossRef]

8. Kulczyński, B.; Gramza-Michałowska, A. Goji Berry (Lycium barbarum): Composition and Health Effects-A Review. Pol. J. Food Nutr. Sci. 2016, 66, 67-75. [CrossRef]

9. Chang, R.C.; So, K.F. Use of anti-aging herbal medicine, Lycium barbarum, against aging-associated diseases. What do we know so far? Cell. Mol. Neurobiol. 2008, 28, 643-652. [CrossRef]

10. Yang, X.; Bai, H.; Cai, W.; Li, J.; Zhou, Q.; Wang, Y.; Han, J.; Zhu, X.; Dong, M.; Hu, D. Lycium barbarum polysaccharides reduce intestinal ischemia/reperfusion injuries in rats. Chem. Biol. Interact. 2013, 204, 166-172. [CrossRef]

11. Amagase, H.; Sun, B.; Borek, C. Lycium barbarum (goji) juice improves in vivo antioxidant biomarkers in serum of healthy adults. Nutr. Res. 2009, 29, 19-25. [CrossRef] [PubMed]

12. Wawruszak, A.; Czerwonka, A.; Okła, K.; Rzeski, W. Anticancer effect of ethanol Lycium barbarum (Goji berry) extract on human breast cancer T47D cell line. Nat. Prod. Res. 2016, 30, 1993-1996. [CrossRef] [PubMed]

13. Shen, L.; Du, G. Lycium barbarum polysaccharide stimulates proliferation of MCF-7 cells by the ERK pathway. Life Sci. 2012, 24, 353-357. [CrossRef] [PubMed]

14. Ceccarini, M.R.; Vannini, S.; Cataldi, S.; Moretti, M.; Villarini, M.; Fioretti, B.; Albi, E.; Beccari, T.; Codini, M. In Vitro Protective Effects of Lycium barbarum Berries Cultivated in Umbria (Italy) on Human Hepatocellular Carcinoma Cells. Biomed. Res. Int. 2016, 2016, 7529521. [CrossRef] [PubMed]

15. Nance, D.M.; Amagase, H.; Luczy-Bachman, G. Effects of Lycium barbarum on basal and LPS-induced cytokine production. Brain Behav. Immun. 2009, 23 (Suppl. S2), S51. [CrossRef]

16. Potterat, O. Goji (Lycium barbarum and L. chinense): Phytochemistry, Pharmacology and Safety in the Perspective of Traditional Uses and Recent Popularity. Planta Med. 2010, 76, 7-19. [CrossRef] [PubMed]

17. Hsu, H.J.; Huang, R.F.; Kao, T.H.; Inbaraj, B.S.; Chen, B.H. Preparation of carotenoid extracts and nanoemulsions from Lycium barbarum L. and their effects on growth of HT-29 colon cancer cells. Nanotechnology 2017, 28, 135103. [CrossRef] [PubMed]

18. Amagase, H.; Farnsworth, N.R. A review of botanical characteristics, phytochemistry, clinical relevance in efficacy and safety of Lycium barbarum fruit (Goji). Food Res. Int. 2011, 44, 1702-1717. [CrossRef]

19. Reeve, V.E.; Allanson, M.; Arun, S.J.; Domanski, D.; Painter, N. Mice drinking goji berry juice (Lycium barbarum) are protected from UV radiation-induced skin damage via antioxidant pathways. Photochem. Photobiol. Sci. 2010, 9, 601-607. [CrossRef]

20. Zhao, H.; Alexeev, A.; Chang, E.; Greenburg, G.; Bojanowski, K. Lycium barbarum glycoconjugates: Effect on human skin and cultured dermal fibroblasts. Phytomedicine 2005, 12, 131-137. [CrossRef]

21. Berra, E.; Diaz-Meco, M.T.; Moscat, J. The Activation of p38 and Apoptosis by the Inhibition of Erk Is Antagonized by the Phosphoinositide 3-Kinase/Akt Pathway. J. Biol. Chem. 1998, 273, 10792-10797. [CrossRef] [PubMed]

22. Xiao, J.; Wang, J.; Xing, F.; Han, T.; Jiao, R.; Liong, E.C.; Fung, M.L.; So, K.F.; Tipoe, G.L. Zeaxanthin Dipalmitate Therapeutically Improves Hepatic Functions in an Alcoholic Fatty Liver Disease Model through Modulating MAPK Pathway. PLoS ONE 2014, 9 , e95214. [CrossRef] [PubMed]

23. Chen, C.; Zhao, S.; Karnad, A.; Freeman, J.W. The biology and role of CD44 in cancer progression: Therapeutic implications. J Hematol. Oncol. 2018, 11, 64. [CrossRef] [PubMed]

24. Magnoni, C.; Giudice, S.; Pellacani, G.; Bertazzoni, G.; Longo, C.; Veratti, E.; Morini, D.; Benassi, L.; Vaschieri, C.; Azzoni, P.; et al. Stem cell properties in cell cultures from different stage of melanoma progression. Appl. Immunohistochem. Mol. Morphol. 2014, 22, 171-181. [CrossRef]

25. Alt, E.; Yan, Y.; Gehmert, S.; Song, Y.H.; Altman, A.; Gehmert, S.; Vykoukal, D.; Bai, X. Fibroblasts share mesenchymal phenotypes with stem cells, but lack their differentiation and colony-forming potential. Biol. Cell. 2011, 103, 197-208. [CrossRef]

26. Tzellos, T.G.; Klagas, I.; Vahtsevanos, K.; Triaridis, S.; Printza, A.; Kyrgidis, A.; Karakiulakis, G.; Zouboulis, C.C.; Papakonstantinou, E. Extrinsic ageing in the human skin is associated with alterations in the expression of hyaluronic acid and its metabolizing enzymes. Exp. Dermatol. 2009, 18, 1028-1035. [CrossRef] 
27. Le Coz, V.; Zhu, C.; Devocelle, A.; Vazquez, A.; Boucheix, C.; Azzi, S.; Gallerne, C.; Eid, P.; Lecourt, S.; Giron-Michel, J. IGF-1 contributes to the expansion of melanoma-initiating cells through an epithelial-mesenchymal transition process. Oncotarget 2016, 13, 82511-82527. [CrossRef]

28. Ahres, T.; Assmann, V.; Fieber, C.; Termeer, C.; Herrlich, P.; Hofmann, M.; Simon, J.C. CD44-is the principal mediator of hyaluronian acid induced melanoma cell proliferation. J. Investig. Dermatol. 2001, 116, 93-101. [CrossRef]

29. Chen, F.; Bi, D.; Cheng, C.; Ma, S.; Liu, Y.; Cheng, K. Bone morphogenetic protein 7 enhances the osteogenic differentiation of human dermal-derived CD105+ fibroblast cells through the Smad and MAPK pathways. Int. J. Mol. Med. 2019, 43, 37-46. [CrossRef]

30. Huang, H.C.; Huang, W.Y.; Tsai, T.C.; Hsieh, W.Y.; Ko, W.P.; Chang, K.J.; Chang, T.M. Supercritical fluid extract of Lycium chinense Miller root inhibition of melanin production and its potential mechanisms of action. BMC Complement. Altern. Med. 2014, 14, 208. [CrossRef]

31. Cheng, J.; Zhou, Z.W.; Sheng, H.P.; He, L.J.; Fan, X.W.; He, Z.X.; Sun, T.; Zhang, X.; Zhao, R.J.; Gu, L.; et al. An evidence-based update on the pharmacological activities and possible molecular targets of Lycium barbarum polysaccharides. Drug Des. Devel. Ther. 2015, 9, 33-78. [CrossRef] [PubMed]

32. Hempel, J.; Schädle, C.N.; Sprenger, J.; Heller, A.; Carle, R.; Schweiggert, R.M. Ultrastructural deposition forms and bioaccessibility of carotenoids and carotenoid esters from goji berries (Lycium barbarum L.). Food Chem. 2017, 218, 525-533. [CrossRef] [PubMed]

33. Weller, P.; Breithaupt, D.E. Identification and Quantification of Zeaxanthin Esters in Plants Using Liquid Chromatography-Mass Spectrometry. J. Agric. Food Chem. 2003, 51, 7044-7049. [CrossRef] [PubMed]

34. Britton, G.; Liaaen, S.; Pfander, H.P. Carotenoids: Isolation and Analysis; Birkhauser Verlag: Basel, Switzerland, 1995.

35. Miklásová, N.; Fischer-Fodor, E.; Lönnecke, P.; Perde-Schrepler, M.; Virag, P.; Tatomir, C.; Cernea, V.I.; Hey-Hawkins, E.; SilaghiDumitrescu, L. Antiproliferative effect and genotoxicity of novel synthesized palladium complexes with organoarsenic ligands. $J$. Inorg. Biochem. 2009, 103, 1739-1747. [CrossRef]

36. Perde-Schrepler, M.; Florea, A.; Brie, I.; Virag, P.; Fischer-Fodor, E.; Valcan, A.; Gurzau, E.; Lisencu, C.; Maniu, A. Size-Dependent Cytotoxicity and Genotoxicity of Silver Nanoparticles in Cochlear Cells In Vitro. J. Nanomater. 2019, 2019, 6090259. [CrossRef]

37. Cenariu, D.; Fischer-Fodor, E.; Virag, P.; Tatomir, C.; Cenariu, M.; Pall, E.; Pintea, A.; Mocan, A.; Crisan, G. In vitro antitumour activity of tomato-extracted carotenoids on human colorectal carcinoma. Not. Bot. Horti. Agrobo. 2015, 43, 293-301. [CrossRef]

38. Tudor, D.; Nenu, I.; Filip, G.A.; Olteanu, D.; Cenariu, M.; Tabaran, F.; Ion, R.M.; Gligor, L.; Baldea, I. Combined regimen of photodynamic therapy mediated by Gallium phthalocyanine chloride and Metformin enhances anti-melanoma efficacy. PLoS ONE. 2017, 12, e0173241. [CrossRef]

39. Pintea, A.; Bunea, A.; Socaciu, C. Effect of esterification on thermal stability and antioxidant activity of zeaxanthin. In Proceedings of the 7th International Congress on Pigments in Food, Novara, Italy, 18-21 June 2013; pp. 174-177, ISBN 978-88-903360-3-4.

40. Inbaraj, S.B.; Lu, H.; Kao, T.H.; Chen, B.H. Simultaneous determination of phenolic acids and flavonoids in Lycium barbarum Linnaeus by HPLC-DAD-ESI-MS. J. Pharm. Biomed. Anal. 2010, 51, 549-556. [CrossRef]

41. Mocan, A.; Vlase, L.; Vodnar, D.C.; Bischin, C.; Hanganu, D.; Gheldiu, A.M.; Oprean, R.; Silaghi-Dumitrescu, R.; Crișan, G. Polyphenolic Content, Antioxidant and Antimicrobial Activities of Lycium barbarum L. and Lycium chinense Mill. Leaves. Molecules 2014, 19, 10056-10073. [CrossRef]

42. Mocan, A.; Cairone, F.; Locatelli, M.; Cacciagrano, F.; Carradori, S.; Vodnar, D.C.; Crisan, G.; Simonetti, G.; Cesa, S. Polyphenols from Lycium barbarum (Goji) fruit European cultivars at different maturation steps: Extraction, HPLC-DAD analyses, and biological evaluation. Antioxidants 2019, 8, 562. [CrossRef]

43. Fonsatti, E.; Del Vecchio, L.; Altomonte, M.; Sigalotti, L.; Nicotra, M.R.; Coral, S.; Natali, P.G.; Maio, M. Endoglin: An accessory component of the TGF-beta-binding receptor complex with diagnostic, prognostic, and bioimmunotherapeutic potential in human malignancies. J. Cell. Physiol. 2001, 188, 1-7. [CrossRef] [PubMed]

44. Ueda, Y.; Richmond, A. NF-kB activation in melanoma. Pigment. Cell. Res. 2006, 19, 112-124. [CrossRef] [PubMed]

45. Breithaupt, D.E.; Weller, P.; Wolters, M.; Hahn, A. Comparison of plasma responses in human subjects after the ingestion of 3R, 3R9zeaxanthin dipalmitate from wolfberry (Lycium barbarum) and non-esterified 3R, 3R9-zeaxanthin using chiral high-performance liquid chromatography. Br. J. Nutr. 2004, 91, 707-713. [CrossRef] [PubMed]

46. Wang, C.C.; Chang, S.C.; Inbaraj, B.S.; Chen, B.H. Isolation of carotenoids, flavonoids and polysaccharides from Lycium barbarum L. and evaluation of antioxidant activity. Food Chem. 2010, 120, 184-192. [CrossRef]

47. Krinsky, N.I.; Johnson, E.J. Carotenoid actions and their relation to health and disease. Mol. Asp. Med. 2005, 26, 459-516. [CrossRef] [PubMed]

48. Bunea, A.; Socaciu, C.; Pintea, A. Xanthophyll esters in fruits and vegetables. Not. Bot. Horti. Agrobo. 2014, 42, 310-324. [CrossRef]

49. Cheng, C.Y.; Chung, W.Y.; Szeto, Y.T.; Benzie, I.F.F. Fasting plasma zeaxanthin response to Fructus barbarum L. (wolfberry; Kei Tze) in a food-based human supplementation trial. Br. J. Nutr. 2005, 93, 123-130. [CrossRef]

50. Granado, F.; Olmedilla, B.; Gil-Martinez, E.; Blanco, I. Lutein ester in serum after lutein supplementation in human subjects. Br. J. Nutr. 1998, 80, 445-449. [CrossRef]

51. Wingerath, T.; Sies, H.; Stahl, W. Xanthophyll esters in human skin. Arch Biochem. Biophys. 1998, 355, 271-274. [CrossRef]

52. Chitchumroonchokchai, C.; Failla, M.L. Hydrolysis of Zeaxanthin Esters by Carboxyl Ester Lipase during Digestion Facilitates Micellarization and Uptake of the Xanthophyll by Caco-2 Human Intestinal Cells. J. Nutr. 2006, 136, 588-594. [CrossRef] 
53. Valluru, M.; Staton, C.A.; Reed, M.W.R.; Brown, N.J. Transforming Growth Factor- $\beta$ and Endoglin Signaling Orchestrate Wound Healing. Front. Physiol. 2011, 2, 89. [CrossRef] [PubMed]

54. Tesic, N.; Kamensek, U.; Sersa, G.; Kranjc, S.; Stimac, M.; Lampreht, U.; Preat, V.; Vandermeulen, G.; Butinar, M.; Turk, B.; et al. Endoglin (CD105) Silencing Mediated by shRNA Under the Control of Endothelin-1 Promoter for Targeted Gene Therapy of Melanoma. Mol. Ther. Nucleic Acids 2015, 4, 239. [CrossRef] [PubMed]

55. Pérez-Gómez, E.; Villa-Morales, M.; Santos, J.; Fernández-Piqueras, J.; Gamallo, C.; Dotor, J.; Bernabéu, C.; Quintanilla, M. A Role for endoglin as a suppressor of malignancy during mouse skin carcinogenesis. Cancer Res. 2007, 67, 10268-10277. [CrossRef] [PubMed]

56. Wang, L.; Ding, Q.Q.; Gao, S.S.; Yang, H.J.; Wang, M.; Shi, Y.; Cheng, B.F.; Bi, J.J.; Feng, Z.W. PRDM5 promotes the proliferation and invasion of murine melanoma cells through up-regulating JNK expression. Cancer Med. 2016, 5, 2558-2566. [CrossRef]

57. Yu, T.; Ji, J.; Guo, Y.L. MST1 activation by curcumin mediates JNK activation, Foxo3a nuclear translocation and apoptosis in melanoma cells. Biochem. Biophys. Res. Commun. 2013, 441, 53-58. [CrossRef]

58. Braicu, C.; Buse, M.; Busuioc, C.; Drula, R.; Gulei, D.; Raduly, L.; Rusu, A.; Irimie, A.; Atanasov, A.G.; Slaby, O.; et al. A comprehensive review on MAPK: A promising therapeutic target in cancer. Cancers 2019, 11, 1618. [CrossRef]

59. Sheng, Y.N.; Luo, Y.H.; Liu, S.B.; Xu, W.T.; Zhang, Y.; Zhang, T.; Xue, H.; Zuo, W.B.; Li, Y.N.; Wang, C.Y.; et al. Zeaxanthin induces apoptosis via ROS-regulated MAPK and AKT signaling pathway in human gastric cancer cells. Oncol. Targets Ther. 2020, 13, 10995. [CrossRef] 